\title{
Biology of procalcitonin and its potential role in veterinary medicine
}

\author{
Review Article \\ Volume: 2, Issue:1 \\ April 2017 \\ Pages: $16-27$
}

Erdal Matur ${ }^{*}$, Evren Eraslan1, Ülker Çötelioğlu1

1. Department of Physiology, Faculty of Veterinary Medicine, University of Istanbul. Avcilar, Istanbul, 34320, Turkey
Article History

Received: 04.04.2017

Accepted: 28.04.2017

Available online: 30.04 .2017

DOI:10.XXXX/XXXX.XX

\begin{abstract}
Procalcitonin is the precursor of calcitonin hormone, produced by $\mathrm{C}$ cells of thyroid gland in physiological conditions. It is also produced in parenchymal cells of many tissues and leukocytes in pathological situations. In the normal condition, procalcitonin is converted by specific enzymes to the calcitonin. Therefore, it is amount in circulation is very low. On the contrary, it increases in the blood and tissue during diseases, because the procalcitonin produced in parenchymal cells cannot be converted to calcitonin. A great number of data has been documented about procalcitonin in human at the physiological and pathological conditions. Furthermore, productions, genetic regulation, kinetics, analysis methods, it is relation with cytokines and diseases have been studied extensively. Consequently, it is used as a reliable biomarker in human medicine, particularly for widespread bacterial infections. However, little is known about the implications in veterinary medicine. In terms of lightening the veterinary field, basic information and new findings on procalcitonin has been reviewed once more, although, quite a few studies have been conducted on procalcitonin in domestic or farm animals. The findings show that production and kinetics of procalcitonin in animals may be quite different, in both of the normal or pathologic conditions. It is not yet used as a biomarker in veterinary medicine. In addition, it has not yet been investigated whether it has an effect on reducing the antibiotics usage in animals.
\end{abstract}

Keywords: procalcitonin, horse, dog, animal, veterinary

\section{Introduction}

Procalcitonin (PCT) is a glycoprotein, consists of 116 amino acids with $13 \mathrm{kDa}$ molecular weight. It is the prohormone of calcitonin. Although calcitonin was discovered in 1962 (Copp and Cheney, 1962), it is precursor PCT entered into publication in 1975 (Moya et al., 1975). Once it was understood that PCT increased in medullary thyroid carcinoma, the studies in this subject accelerated and it is molecular structure was defined for the first time in 1981 (Jacobs et al., 1981). Later on, Bohuon (2000) and his coworker who have been conducting biomarker research in thyroid cancers, found high PCT levels in small cell carcinoma of lungs. This finding has attracted more attention to PCT studies. During the Gulf War in 1991, a group of researchers interested in markers of severe lung injury due to inhalation of toxic gas. They found that, PCT level increased in soldiers affected by poisonous gas. Retrospective studies on soldiers showed that patients suffered from severe sepsis and septic shock. Two years

* Corresponding Author: Erdal Matur, Istanbul University, Faculty of Veterinary Medicine Department of Physiology.

E mail: mature@istanbul.edu.tr after this publication Assicot el al. (1993) reported about significant elevation of PCT production in extrathyroidal tissues during bacterial infection or sepsis. This important finding opened a new avenue on the clinical studies about PCT. Currently, it became an effective biomarker used in infectious diseases or noninfectious inflammatory condition in human medicine (Lee, 2013; Grace and Turner, 2014)

\section{Genetic regulation of procalcitonin}

Procalcitonin production is regulated by calcitonin gene -1 (CALC-1) gene in 11th chromosome in human (Becker et al., 2010). The CALC-1 gene is composed of 6 exons, 5 introns, and a promoter region containing several consensus sites for inflammatory transcription factors. Alternative splicing of the CALC-I gene results in two separate transcripts: preprocalcitonin (composed of 141 amino acids) and calcitonin gene-related peptide (CGRP). Preprocalcitonin consist of signal peptide http://dergipark.gov.tr/http-www-jivs-net 
(composed of 25 amino acids) and PCT (composed of 116 amino acids). Once translated, preprocalcitonin moves to an endoplasmic reticulum, where it is signal peptide is cleaved to generate PCT. Subsequently, PCT is cleaved by specific endopeptidases to liberate three peptide products: N-procalcitonin (composed of 57 amino acid), calcitonin (composed of 32 amino acid), and katacalcin (composed of 21 amino acid) (LeMoullec et al., 1984; Russwurm et al., 1999). N-procalcitonin has been localized in adipocytes and neuroendocrine cells as well as in some hypothalamic regions of primary importance in the regulation of feeding and energy balance (Tavares et al., 2007). Calcitonin participates in calcium and phosphorus metabolism and counteracts parathyroid hormone (Copp and Cheney, 1962). Katacalcin, like calcitonin, may be involved in both plasma calcium regulation and skeletal bone maintenance (Hillyard et al., 1983).

\section{Procalcitonin synthesis}

Procalcitonin production is regulated by CALC- 1 gene in both physiological and pathological conditions (Liu et al., 2015). It is produced by parafollicular cells (C cells) in thyroid gland and small amount in K cells in lung at the physiological condition, which is named as thyroidal or neuroendocrine production. It is produced in parenchymal cells and leukocytes in pathological conditions, which is called extra thyroidal production. In the normal condition PCT synthesized by $\mathrm{C}$ cells and it converts to the mature calcitonin hormone, stored in secretory granules and released after appropriate stimulation (Becker et al., 2001; Muller et al., 2001). Meanwhile extra-thyroidal transcription of the CALC I gene is suppressed and synthesis of PCT is restricted in C cells (Christ-Crain and Muller, 2007), Therefore, in human concentration of PCT in circulation is below 0.1 $\mathrm{ng} / \mathrm{mL}$. In the physiologic condition, C-cells are stimulated by hypercalcemia, $\beta$-adrenergic stimulation, increased concentrations of glucocorticoids, CGRP, glucagon, and gastrin. Conversely, C cells are suppressed by vitamin D and somatostatin (Maruna et al., 2000).

\section{Extra-thyroidal procalcitonin synthesis}

Parenchymal cells producing PCT during severe bacterial infections or inflammation. Procalcitonin is also called as "hormokin". It is synthesized by endocrine glands in physiological conditions like hormones, but is released in large amount by various tissues during inflammation as same as cytokines (Christ-Crain and Muller, 2007). Pancreas, liver, spleen, adrenal gland, lung, kidneys, brain, spinal cord, testes, stomach, small intestine, colon visceral fat, skin, peritoneal macrophages and leukocytes are the principle extrathyroidal production sites for PCT (Müller et al., 2001). Supporting extra-thyroidal production, it has been reported that serum PCT levels increased after LPS injection in olive baboons (Morgenthaler et al., 2003).

Procalcitonin synthesized in C cells is degraded to peptides such as calcitonin or katacalcin by endopeptidases. Because this enzyme is not present in parenchymal tissues, synthesized prohormone is released as PCT to circulation without degradation process (Linscheid et al., 2004). Therefore, procalcitonin levels prominently increases in short time although there is no significant change in calcitonin levels (Durnaś et al., 2016).

Procalcitonin as a biomarker of infectious diseases

Bacterial infections: In the normal condition, secretion of calcitonin is stimulated vast majority by hypercalcemia. On the other hand, in the bacterial infection or sepsis, both lipopolysaccharides (LPS) from the bacterial cell wall and inflammatory cytokines, such as interleukin-1 beta (IL-1 $\beta$ ), IL-6 and tumor necrosis factor-alpha (TNF- $\alpha$ ) stimulate the production of PCT. These cytokines lead to PCT release by increasing CALC1 gene transcription. Indeed, it has been postulated that this sepsis-related increase of CALC-I gene transcription is mediated by stimulus-specific response elements within the promoter gene (Domenech et al., 2001).

Local bacterial infection: Although PCT synthesis increases in bacterial infections, level of this increase is depend on whether the infection is local or widespread. Thousand-fold increase in PCT levels may occur in a few hours to widespread infections or sepsis, but the level of increase is limited in local bacterial colonization such as tonsillitis, minor soft tissue infections, and abscess. In fact some infections such as local appendicitis or cholecystitis usually do not induce PCT synthesis. It has been reported that human serum PCT levels were above $1.0 \mathrm{ng} / \mathrm{mL}$ in bacteremia and above $2.0 \mathrm{ng} / \mathrm{mL}$ in septic 
response but at $0.5-1.0 \mathrm{ng} / \mathrm{mL}$ levels in local infections (Carrol et al., 2002). Therefore, PCT level may not be a good diagnostic marker for local bacterial infection (Hirakata et al., 2008; Meisner, 2014).

Type of the agent in bacterial infections: Synthesis of PCT from extra-thyroidal tissues in bacterial infections is also related to the type of the bacterial load that caused the infection. Procalcitonin levels are as high as the bacterial load. Increase in PCT is also depend on whether the agent is positive or negative. Gram negative bacteria cause more PCT release than gram positive. Actually, gram-positive bacteria activate the Toll-like receptor-2 (TLR-2) pathway, whereas gramnegative bacteria the Toll-like receptor-4 (TLR-4) pathway, resulting in different production of inflammatory cytokines, that ultimately stimulate ubiquitous transcription of calcitonin-mRNA and release of PCT from multiple tissues throughout the body (Leli et al., 2015). Furthermore, type of the agent is significant. It was reported that human serum PCT level were above $2 \mathrm{ng} / \mathrm{mL}$ in Chlamydia, Streptococcus pneumoniae, Staphylococcus aureus infections, were at 5 -2 ng/mL in Escherichia coli, Pneumocystis carinii, Leptospira and Pseudomonas aeruginosa infections and were below $1 \mathrm{ng} / \mathrm{mL}$ in Coxiella burnettii, Citrobacter freundeii, Salmonella, infections (Delèvaux et al., 6447).

Viral infection: Cell fragments emerged during viral infections cause to interferon gamma (IFN- $\gamma$ ) secretion in large quantities (Melendi et al., 2007). Interferon gamma does not stimulate CALC-I gene transcription on the contrary to IL- $1 \beta$ and TNF- $\alpha$ released during bacterial infections. In fact, it may exert the effect by inbition of IL-1 $\beta$. Thus it has been reported that PCT level marked increased in 15.2-fold in hours in adipocyte cell culture model by IL- $1 \beta$, but synthesis of PCT is blocked by IFN- $\gamma$ (Linscheid et al., 2003). This finding explain that PCT level don not elevate too high in viral infections mixed by bacterial contamination. Because in viral infections the host $\mathrm{T}$ helper lymphocytes are forced to produce IFN- $\gamma$ which has a negative feed-back effect on the synthesis of IL-1 $\beta$ (Becze et al., 2016).

Fungal infection: $\beta$-glucan and mannosidases in the cell wall of fungus stimulate IFN- $\gamma$ and IL-17 synthesis in fungal infections. These cytokines lead to blockage of procalcitonin synthesis. Thus, PCT level is quite low in fungal infections. However, mixed infections caused by both bacterial and fungal agents overcome the blocking effects of IFN- $\gamma$ and IL-17. Therefore, PCT levels increase in mixed bacterial and fungal infections. But this elevation is not as high as in bacterial infections. (Becze et al., 2016). Montagna et al. (2011) reported that fungal infections caused a moderate increase, ranging from 0.5 to $1.0 \mathrm{ng} / \mathrm{mL}$, in intensive care patients. Consequently, serum PCT level may provide some useful clinical information for differentiation between invasive fungal disease and bacterial infection (Dou et al., 2013).

\section{Non-infectious causes of elevated procalcitonin}

Other than bacterial infections, some clinical conditions may cause an increase in PCT. One of the most common cases in human are tumors. Medullar carcinoma of thyroid gland, small cell carcinoma of lung, bronchial carcinoma or neuroendocrine tumors of the gastrointestinal system causes to elevation at PCT levels. It also increases by severe noninfectious inflammatory stimuli such as acute multiorgan failure, major burns, acute sterile pancreatitis, severe trauma, or major abdominal or cardiothoracic surgery (Becze at al., 2016), In addition, Kawasaki disease (Okada et al., 2004) graft-versus-host disease (aGvHD) and T-cell antibody infusion (Dornbusch et al., 2008) or heatstroke (Aggarwal and Schauer, 2013) also cause PCT production in extra-thyroidal tissue. TNF- $\alpha$ and released cytokines or other molecules related to tissue damage are considered to stimulate PCT synthesis. Procalcitonin level is elevates first 24-48 hours and later declines (Becze at al., 2016). Furthermore, PCT level is physiologically high in newborn during first couple of days. This may be due to response of innate immune system to microbiota settling in gastro intestinal truck.

\section{Kinetics of procalcitonin}

Because it is synthesized in extra-thyroidal tissues during infections, it is level elevates rapid between 2-4 hours and reaches to the highest in 6 hours (Dandona et al., 1994; Brunkhorst et al., 1998). Procalcitonin level reported to increase 10.000 fold higher than the normal in widespread bacterial infections or sepsis $(1 \mathrm{ng} / \mathrm{mL}$ to $1000 \mathrm{ng} / \mathrm{mL}$ ) (Assicot et al., 1993). It also sustains in this high level during the infection (Lee, 2013). However, it was reported that it is plasma level decreased by $50 \%$ at 24-36 hours after reaching the highest level (Meisner, 1997). In addition, it was found that PCT level returned very rapid to normal with healing process and decreased to $0.5 \mathrm{ng} / \mathrm{mL}$ in 24 hours (Meisner, 1997).

\section{Elimination of procalcitonin}

The half-life of PCT is approximately $25-35$ hours. It is 
It is degrading by proteolysis like the other plasma proteins in the liver (Steinbach et al. 2004). It has not been defined a specific pathway for elimination of PCT (Ertuğrul and Ertuğrul, 2005). Renal elimination is not a major mechanism for PCT removal from the plasma. However, it is reported that the plasma disappearance rate may be prolonged up to $30-50 \%$ in some patients with renal dysfunction (Grace and Turner, 2014). Similarly, it has been also reported that, serum PCT levels are significantly higher in patients with chronic kidney disease without a history of dialysis or infection compared with healthy individuals (Meisner et al., 2001). Some evidence suggests an indirect effect of renal disease on PCT levels, as it is postulated that decline in renal function may result in elevation of serum proinflammatory metabolites, which stimulate the immune system, resulting in enhance inflammation and release of PCT into the circulation (Dahaba et al., 2003).

\section{Physiological role of procalcitonin}

Physiological role of PCT has not been defined clearly, although there are many studies conducted about PCT (Davies, 2015). The studies on PCT shows that there are not specific receptors for PCT in the tissues, it does not have affinity to calcitonin receptors although $\mathrm{Ca} 2+$ requirement increases in sepsis, thus it is not related to calcium metabolism (Maruna et al., 2000). It may be questioned why it increases in infections and what it is function in plasma. There are studies reporting about connection to immune system, coagulation cascade, vessel functions and apoptosis (Araujo et al., 2013).

One of the extra-thyroidal production sites for PCT is leukocytes. It is first released by neutrophils in small amount and afterwards by tissue macrophages during infections (Meisner, 2014). While tissue PCT is released without macrophages being present in the tissue, macrophages increase the release of tissue PCT (Linscheid et al., 2003). Procalcitonin is considered as a component of the immune system, because inflammatory cytokines such as TNF- $\alpha$ IL- $1 \beta$ and IL- 6 are also effective on it is release. However, during an infection the greater PCT mRNA induction and PCT peptides release from parenchymal cells compared to circulating cells indicate a tissue-based rather than leukocyte-based host defense mechanism (Liu et al., 2015). In fact, high level of PCT in patients with neutropenia or immune suppression support this suggestion. Although interrelation between PCT and immune system has been acknowledged, whether PCT is helpful or detrimental to the host is uncertain. Exogenous PCT administration to healthy animals did not induce clinical symptoms but worsen the condition in septic animals and the mortality rate increased. Procalcitonin antibody administration, eliminating PCT in circulation, reported to cause a decrease in mortality (Nylén et al., 1998). Furthermore, it was reported that, physiological and metabolic parameters returned to the favor of the host in pigs that were applied PCT antiserum during the early periods of sepsis (Wagner et al., 2002). For these reasons it has been suggested that PCT functions against to the host. On the other hand, it is considered that it may be in favor of the host to recognize the invading agent (Gilbert, 2011). It has been reported that acute effects of PCT on neutrophils and leukocytes are proinflammatory (Wei et al., 2008). It also accelerates monocyte migration to infection area by decreasing monocyte attachment to vessel surface (Wiedermann et al., 2002).

Procalcitonin also may have a nonsteroidal analgesic effect. It exerts this effect by inhibiting Prostaglandin-G and $\mathrm{H}$ synthesis (Maruna et al., 2000). It was found that PCT inhibited arachidonic acid-induced prostaglandin synthesis in lymphocytes in vitro. Prostaglandins and arachidonic acid, they both sustain homeostatic functions and mediate pathogenic mechanisms, including the inflammatory response (Ricciotti et al., 2011).

Procalcitonin may also have an effect on smooth muscles of vessels. Procalcitonin inhibited thromboxane synthesis in lymphocytes in vitro (Meisner, 1996). Inhibition of thromboxane, which is a vasoconstrictor, causes relaxation in vessel muscles and this may be influential in heart stroke. In fact, it was reported that PCT caused to a small vasodilator response in coronary arteries in pigs (Wei et al., 2008). On the other hand, PCT suppressed nitric oxide synthesize gene induced by cytokines in smooth muscle cells in vitro. This might be a counter regulatory mechanism directed against the large production of nitric oxide and the concomitant systemic hypotension in severe sepsis and septic shock (Hoffmann et al., 2001). There are some studies reporting a relation between PCT and apoptosis. Because there are 
similarities in amino acid sequences between PCT and apoptosis regulating intracellular components such as BCL-2 family, caspases, death domain profile, actin depolymerizing proteins (Russwurm et al., 1999). In fact, PCT caused apoptosis in mesangial cells of glomerulus in vitro (Araujo et al., 2013).

\section{Procalcitonin as a clinical biomarker}

Procalcitonin has become an efficient diagnostic biomarker in clinic after acknowledging that PCT increases in bacterial infections and sepsis but not in viral infections in human (Müller et al., 2001). In addition, the increase level of PCT is different in each condition. For example, the elevation level is different in common bacterial infections compare to non-infectious inflammation, tissue damage or post-surgical periods. Furthermore, it is used effectively to determine the degree of the infection. For example, it is defined as sepsis if PCT level is between $2-10 \mathrm{ng} / \mathrm{mL}$, as severe sepsis when the level is above $10 \mathrm{ng} / \mathrm{mL}$ and when PCT level below $0.2 \mathrm{ng} / \mathrm{mL}$ it indicated that there is not sepsis or systemic inflammation (Chivate et al., 2016).

Procalcitonin is more advantageous compared to the other non-specific biomarkers used in clinics such as $\mathrm{C}$ reactive protein (CRP), cytokines, or sedimentation rate, due to higher sensitivity and specificity. Increasing period of it is level during infection is shorter. Moreover, amount of the increase is more prominent (Lee, 2013). In the absence of ongoing sepsis, PCT will normalize within 2-3 days of induction, making it potentially more useful in monitoring human patients than CRP, which remains elevated for 3-7 days (Schneider and Lam, 2007). In addition, the stability of PCT ensures that an early peak and fall is not missed, as is often the case with cytokines such as TNF- $\alpha$ and IL-6. Procalcitonin is an important parameter to decide whether to use an antibiotic or not. It is also used to decide whether the given antibiotic was beneficial or not and for determining the end of the treatment. Because it is half- life is short, PCT level drops rapidly when healing period begins. Procalcitonin level decreases by $30 \%, 24$ hours after the healing process begins (Hatzistilianou, 2010).

Procalcitonin is also used as a biomarker in infectious disease for monitoring prognosis. Increased level of PCT in septic patients indicate that prognosis is not good. On the other hand, a decrease in PCT shows that applied treatment is successful (Mehanic and Baljic, 2013).
It is very beneficial that plasma PCT level is not affected by glucocorticoids, nonsteroidal anti-inflammatory agents, neutropenia, immunosuppression, viral diseases and kidney disorders. That is why PCT is place forward compared with the other clinical biomarkers.

\section{Procalcitonin usage in clinics}

Procalcitonin is used for diagnosis of common bacterial diseases, especially of sepsis in clinics. It also gives information about whether the infection is viral or bacterial. Procalcitonin level is also a parameter used for various clinical conditions. Main clinical conditions in which PCT is used are; differential diagnosis between infection and sterile necrosis in acute pancreatitis, determination of etiology for idiopathic infectious diseases with high fever, identifying whether the agent is bacterial or viral in autoimmune diseases, monitoring immune suppressive patients in oncology and hematology, monitoring neutropenic patients after chemotherapy, differential diagnosis between acute organ rejection or viral infection and bacterial infection after transplantation (Ertuğrul and Ertuğrul, 2005). It is verified that serum PCT is the most reliable parameter in differentiating between viral and bacterial meningitis evaluating PCT and lactate parameters together. It is important to note that surgery, severe trauma, heat shock, burns, prolonged cardiogenic shock, and severe systemic inflammatory response syndrome (SIRS) have also been associated with elevation in PCT in people. (Meisner et al., 2001). Up-regulation of proinflammatory mediators in the absence of bacteria is likely the cause for this increase; however, in each of these patient cases, elimination kinetics of the hormokine shows a rapid decline in PCT. Persistently elevated PCT concentrations can therefore be used to distinguish sepsis or septic complications to other conditions (Floras et al., 2014).

\section{Assay methods}

The first PCT assays were based on immunochemistry methods. These assays have been replaced by fully automated immunochemistry methods. Recently, the PCT assay has been modified for use on a consolidated routine immunochemistry analyzer system. Currently analyses systems use principles of immunofluorescence, electrochemiluminescence, chemiluminescence and enzyme-linked fluorescence assay. Measuring range, functional sensitivity, detection limits of these methods 
varies depending on the used technic and assay. Measuring range, functional sensitivity and detection limit differ between $0.02-500 \mathrm{ng} / \mathrm{mL}, 0.05-0.24 \mathrm{ng} / \mathrm{mL}$, 0.019-0.05 ng/mL, respectively (Davies, 2015). In addition, there is a test called "point-of-care testing, or bedside testing" which is a rapid test (BRAHMS procalcitonin $Q \circledR$ test) carried out in the places where patients have their treatments. This rapid assay is a semi-quantitative immunochromatographic test that provides a result within 30 minutes. Monoclonal mouse anti-katacalcin and polyclonal sheep anti-calcitonin antibodies capture PCT to result in a colored band with an intensity that reflects the concentration of PCT in the sample. This semi-quantitative test is acceptable, because a PCT concentration of up to $0.1 \mu \mathrm{g} / \mathrm{L}$ is considered normal, whereas a greater than 10 -fold increase $(2-10 \mu \mathrm{g} / \mathrm{L})$ is required for a diagnosis of severe sepsis. The assay is unreliable in the presence of hemolysis (Floras et al., 2014). For the research purposes PCR technics have been used to measure PCT for years except these technics. There are no studies precisely defining the optimum time course for PCT measurement, whether trends or absolute levels should be used and what the appropriate action is depending on the result.

\section{Procalcitonin studies on animals}

There is limited number of PCT studies on domestic animals, although calcitonin first discovered in experimental studies in dogs (Copp and Cheney, 1962) and afterwards various experimental animals were used such as rat, pig, and baboon. Procalcitonin is widely used in intensive care units, infection clinics and in the other areas in human, but interestingly there is no clinical use of PCT in veterinary medicine.

\section{Procalcitonin studies on experimental animals}

In vivo PCT studies have been carried out mostly on experimental animals. It was reported that PCT only expressed in thyroid and lungs in healthy golden hamsters, but in septic hamsters conveyed in thyroid gland, spleen, liver, pancreas, kidney, adrenal gland, brain, spine, colon, testes, fat, skin, stomach, peripheral leukocytes and peritoneal macrophages (Müller et al., 2001). Procalcitonin expression were also found in liver, lung, kidney, adrenal, colon, skin, spleen, brain, pancreas, mononuclear leukocytes and endothelial cells in animals closer to human such as pig (Zannoni et al, 2012), and baboon (Morgenthaler et al., 2003) after LPS administration. Both small and big experimental animals were used for examining PCT toxicity and neuroimmunization. Nylén et al. (1998) did not detected significant toxic effect after intravenous injection of PCT to healthy hamsters, however toxic effect increased and mortality rate were close to $100 \%$ after PCT injection to septic ones. Mortality decreased significantly by applying antiserum (reactive to the midregion of the CT molecule) to septic hamsters (Nylén et al., 1998). Similarly, it was reported that, antiserum (reacting with the amino terminal site of PCT) application during the early periods of sepsis affected physiological and metabolic parameters positively in pigs Wagner et al. (2002). Immunoneutrolization in later period in septic pigs increased the survival rate significantly by affecting physiological and metabolic parameters positively (Martinez et al., 2001).

\section{Procalcitonin studies on dogs}

Procalcitonin is expressed by CACL-1 gene in dogs as in human. Amino acid sequence and molecular structure of PCT were defined at 1991 by Mol et al. (1991). Dog PCT has a homology within the amino acid sequence to the human PCT with $67 \%$, rat $74 \%$, sheep $60 \%$, chicken $45 \%$ and salmon $43 \%$ with large differences noted in the katacalcin region (Mol et al., 1991; Russwurm et al., 1999).

There are only few studies in dogs examining the relation between PCT synthesis and diseases. Giunti et al. (2010) examined the expression of PCT gene in thyroid, liver, spleen, and lung tissues obtained from 9 dogs died from parvoviral infection or SIRS and from 5 health dogs. They found that CALC-1 gene is expressed only in thyroid but not in other tissues in healthy dogs. CALC-1 gene is expressed in spleen, lung and liver of 6 , 4 and 3 out of 9 diseased dogs respectively. In the same study, CALC-1 gene expression was reported in thyroid, spleen and lung tissues of a dog which gave a noninfectious anti-inflammatory response. Because these findings are not quantitative, they were not used for discriminating between septic and non-septic animals. Kuzi et al. (2008), measured mRNA expression of PCT in peripheral leukocytes of healthy and unhealthy dogs. Unhealthy dogs were grouped as infectious, noninfectious inflammatory, neoplastic, and other diseases. Procalcitonin mRNA abundance was higher in unhealthy dogs than control group, however there was not a significant difference between infectious, 
noninfectious, inflammatory or neoplastic groups. They concluded that extra-thyroidal PCT is mainly synthesized in parenchymal tissues during diseases, synthesis by leukocytes is limited.

To our knowledge, serum PCT level were measured in a very limited numbers of study in dogs. Because sequence differences with the human peptide preclude cross-reactivity of canine PCT with assay for human PCT. The gene for PCT was cloned, expressed, and recombinant protein purified for use in generating a canine specific quantitative PCT ELISA for clinical use by Floras (2014) in cooperation with North Carolina State University. However, the test were reported failed in discriminate between septic infection and non-septic SIRS. Furthermore, Floras et al. (2014) reported that one of the commercial ELISA kits measuring serum PCT level in dogs has intra-assay variability between 18.9$77.4 \%$, and inter-assay variability between 56.1-79.5 $\%$, and therefore this kit is not suitable for PCT measurement in dogs. There are two other studies measured serum PCT level, Serum PCT level was reported to increase after endotoxin application in dogs study (Yllmaz et al., 2008). The other study show serum PCT level increased in dogs had Babesia canis infection (Brkljačić et al., 2014). However, the effects of the other parasites, which were observed widely in the same area, on PCT levels have not been investigated. There is no a clinical study on this subject and it is not used as a clinical marker in dogs until now.

\section{Equine procalcitonin}

The equine PCT consist of 115 amino acids with a molecular weight of $12.5 \mathrm{kDa}$. Equine PCT has a homology within the amino acid sequence to the human PCT with $83 \%$, rat $74 \%$, sheep, canine and mouse 73 $\%$, chicken $59 \%$ and salmon $58 \%$ with large differences noted in the katacalcin region (Toribio et al., 2003). Procalcitonin is used in human medicine as a sensitive marker for the presence of a bacterial infection and endotoxemia. In comparison to other species horse is very sensitive to the systemic consequences of endotoxemia leading to a high morbidity and mortality. For this reason, PCT may be used as a reliable biomarker in horses. Recently Bonelli et al. (2017) studied PCT kinetics in horses that were infused LPS intravenously. Extra-thyroidal PCT synthesis reach to the highest point 6 hours after LPS stimulation (Dandona et al., 1994; Brunkhorst et al.,
1998), this time was longer in horses, the highest level were found 24 hours after the stimulation. Procalcitonin level increased gradually similar to human; $28.5 \mathrm{ng} / \mathrm{mL}$ at the beginning and $271 \mathrm{ng} / \mathrm{mL}$, after 24 hours. Although PCT level is very low to be detected in physiological condition in human, PCT level were traced to be high even in physiological condition in horses. This difference is likely due to the different species studied. The normal intestinal equine flora is composed of large quantities of gram-negative bacteria, thus large amounts of LPS normally exist in the equine intestinal lumen, especially in the large hindgut (Costa et al., 2015). Also in healthy horse small amounts of LPS may cross the intact mucosal barrier and reach the portal circulation and the liver (Dicks et al., 2014). This small amount of LPS could lead to slightly higher basal PCT concentrations in horses (Bonelli et al., 2017).

Procalcitonin studies are more in horses than in the other domestic animals. Pusterla et al. (2006) reported that there was not a significant difference in leukocyte PCT mRNA levels between septic and non-septic foals. Therefore, PCT gene expression in leukocytes cannot be used to differentiate between septic and non-septic inflammatory diseases in horses. On the other hand, Rieger et al. (2014) reported that PCT level changed between 2.593 to $198.520 \mathrm{ng} / \mathrm{mL}$ in septic horses but it was $47 \mathrm{ng} / \mathrm{mL}$ in the control group, therefore it may be used as a biomarker in horses to detect sepsis. Teschner et al. (2015) found that PCT level is quite high in horses that have colic due to endotoxemia $(385.3 \mathrm{ng} / \mathrm{mL}$ in control group, average of $90.625 \mathrm{ng} / \mathrm{mL}$ in endotoxic group, maximum: $227.989 \mathrm{ng} / \mathrm{mL}$, minimum: $24 \mathrm{ng} /$ mL). Similarly, Bonelli et al. (2015), determined significantly increased PCT level in horses with SIRS (Healthy: $28 \pm 20.32 \mathrm{pg} / \mathrm{mL}$ and SIRS: $197.0 \pm 117.0 \mathrm{pg}$ / $\mathrm{mL}$ respectively). Furthermore, PCT level in SIRS group was different than of disease group (strangulated intestinal lesion: $232 \pm 155 \mathrm{pg} / \mathrm{mL}$, non-strangulated intestinal lesion: $148 \pm 79 \mathrm{pg} / \mathrm{mL}$, diarrhea or colitis: $168 \pm 79 \mathrm{pg} / \mathrm{mL}$ pleuropneumonia: $217 \pm 155 \mathrm{pg} / \mathrm{mL}$ ). Moreover, plasma PCT level increased significantly in horses that have pneumopaties (Healthy horses 13.94 $\mathrm{ng} / \mathrm{mL}$, unhealthy horses $174.46 \mathrm{ng} / \mathrm{mL}$ ). (Barton et al., 2016).

Procalcitonin level may be measured in bronco alveolar fluid (BALF) in bronco alveolar disorder as leukocyte infiltration occurs to the area and both neutrophils and macrophages secrete PCT during the infection. In fact, it 
was reported that BALF PCT level increased in horses with chronic pneumopaties (Barton and Gehlen, 2016). Barton et al. (2016) also measured plasma and BALF PCT levels in horses with chronic pneumopaties. There is a correlation between plasma and BALF PCT, but PCT in BALF does not seem to be a superior marker compared to established clinical markers, in particular in cases of low-grade inflammation. Plasma PCT levels of horses that had laparotomy surgery due to acute colitis were also higher than that of healthy horses $(27.544 \mathrm{ng} / \mathrm{mL})$. Procalcitonin level was still at the high even after 72 hours later (Teschner et al., 2015).

\section{Ruminant procalcitonin}

There is only a few study on ruminants, as far as we know. In one of these studies, no significant differences was found in serum PCT level in healthy cattle between genders, but neonatal calves had higher PCT level than young and adult cattle (Ercan et al. 2014). In addition same researchers reported that, PCT concentrations were significantly higher in neonatal calves with septicemic colibacillosis compared with controls, and there was a positive correlation between PCT and the pro-inflammatory cytokines such as TNF- $\alpha$ and INF- $\gamma$ (Ercan et al., 2016).

\section{Conclusion}

Calcitonin was first discovered by the experimental studies conducted on dogs (Copp and Cheney, 1962) and afterwards various animals such as rats, pigs, baboons were used, however PCT studies on domestic animals are very limited. A great number of data was presented about PCT synthesis in human at physiological and pathological conditions. Furthermore, genetic regulation, expression, kinetics of PCT and it is

\section{References}

Aggarwal, S. \& Schauer, M. (2013). Not every rise in procalcitonin is infection. Journal of Case Reports and Studies 1(2), 1-2.

DOI: 10.15744/2348-9820.1.203.

Araujo, M., Doi, S. Q., Palant, C. E., Nylén, E. S. \& Becker, K. L. (2013). Procalcitonin induced cytotoxicity and apoptosis in mesangial cells: implications for septic renal injury. Inflammation Research, 62(10), 887-894.

DOI: $10.1007 / \mathrm{s} 00011-013-0646-8$.

Assicot, M., Gendrel, D., Carsin, H., Raymond, J., Guilbaud, J. \& Bohuon, C. (1993). High serum procalcitonin concentrations in patients with sepsis and infection. Lancet, 341(8844), 515-518. relation with cytokines and diseases have been studied extensively. Procalcitonin level in various diseases were determined. Methods were developed and validated to measure PCT level in plasma and tissues and they were adapted to auto analyzer systems. Consequently, it is used as a reliable biomarker in clinics in human medicine. However, there is only limited number of studies on PCT in veterinary medicine except experimental animals. Genetic regulation, molecular structure, synthesis in physiological and pathological conditions, kinetics of PCT and it is relation with cytokines should be studied further in domestic animals. Amino acid sequence of PCT differs between species. Therefore, species specific antibodies are need for quantitative assays of PCT by ELISA. Furthermore, sensitivity and specificity values of developed test should be at reasonable rang. The assay methods should be improved to use PCT as a biomarker in veterinary medicine. Reference values should be obtained and set, cut-off values need determined to standardize measurements and to interpret results in animals. It is also still unknown whether it can be used to detect prognosis for chronic disease in animals. Similarly, extra-thyroidal PCT synthesis changes have not been studied yet in noninfectious inflammatory diseases, traumas and surgeries. Furthermore, using PCT neuroimmunization as a treatment option, which is used in human currently, should be studied in animals. Procalcitonin is used to limit antibiotic usage in human, as it enables to early period diagnosis in bacterial diseases. Similarly, it will possibly decrease the need for antibiotics in farm animals by enabling early period diagnosis. Therefore, studies of PCT in animals will have favorable effect on both animal and human health.

Barton, A. K. \& Gehlen, H. (2016). Pulmonary remodeling in equine asthma: What do we know about mediators of inflammation in the horse? Mediators of Inflammation, 111.

DOI: http://dx.doi.org/10.1155/2016/5693205

Barton, A. K., Pelli, A., Rieger, M. \& Gehlen, H. (2016). Procalcitonin as a biomarker in equine chronic pneumopathies. BMC Veterinary Research, 12(6 $\left.6^{2} 5\right)$, 5-7. DOI: 10.1186/s12917-016-0912-4

Becker, K. L., Muller, B., Nylén, E., Cohen, R., Silva, O. L. \& Snider, R. (2001). Calcitonin Gene family of peptides. In K. L. Becker (Ed.). Principles and Practice of Endocrinology and Metabolism, 3rd ed. (pp. 964-533). Philadelphia, USA. J. B. Lippincott Co. 
Becker, K. L., Snider, R. \& Nylén, E. S. (2010). Procalcitonin in sepsis and systemic inflammation: A harmful biomarker and a therapeutic target. British Journal of Clinical Pharmacology, 159(6), 697-264. DOI: 10.1111/j.14765381.2009.00433.x

Bohuon C. (2000). A brief history of procalcitonin. Intensive Care Medicine, 26(Suppl 2), S146-S147. DOI: $10.1007 /$ BF02900727.

Becze, Z., Molnár, Z. \& Fazakas, J. (2016). The molecular basis of procalcitonin synthesis in different infectious and noninfectious acute conditions. Journal of Human Virology and Retrovirology, 3(2), 1-4. DOI: 10.15406/jhvrv.2016.03.00085.

Bonelli, F., Meucci, V., Divers, T. J., Jose-Cunilleras, E., Corazza, M., Tognetti, R., Guidi, G., Intorre, L. \& Sgorbini, M. (2015). Plasma procalcitonin concentration in healthy horses and horses affected by systemic inflammatory response syndrome. Journal of veterinary internal medicine, 29(6), 1689-1691.

DOI:10.1111/jvim13640

Bonelli, F., Meucci, V., Divers, T. J., Wagner, B., Intorre, L. \& Sgorbini, M. (2017). Kinetics of plasma procalcitonin, soluble CD14, CCL2 and IL-10 after a sublethal infusion of lipopolysaccharide in horses. Veterinary Immunology and Immunopathology, 184, 29-35.

DOI: $10.1016 /$ j.vetimm.12.010.

Brkljačić, M., Torti, M., Pleadin, J., Mrljak, V., Šmit, I., Kiš, I, , Mayer, I., Crnogaj, M. \& Matijatko, V. (2014). The concentrations of inflammatory markers the aminoterminal portion of C-type pronatriuretic peptide and procalcitonin in canine babesiosis caused by Babesia canis. Veterinarski Arhiv, 40(6), 575-589.

Brunkhorst, F. M., Heinz, U. \& Forycki, Z. F. (1998). Kinetics of procalcitonin in iatrogenic sepsis. Intensive Care Medicine, 24(8), 888-889. DOI: $10.1007 / \mathrm{s} 001340050683$.

Carrol, E. D., Thomson, A. P. J. \& Hart, C. A. (2002). Procalcitonin as a marker of sepsis. International Journal of Antimicrobial Agents, 20(1), 1-9.

DOI: http://dx.doi.org/10.1016/S0924-8579(02)00047-X

Chivate, C. G., Belwalkar, G. J., Limaye, R. P. \& Patil, R. V. (2016). Procalcitonin as a marker for the diagnosis of sepsis. International Journal of Research in Medical Sciences 4(4):1216-1218.

DOI: http://dx.doi.org/10.18203/2320-6012.ijrms20160812

Christ-Crain, M. \& Muller, B. (2007). Biomarkers in respiratory tract infections: Diagnostic guides to antibiotic prescription prognostic markers and mediators. European Respiratory Journal, 96(3), 556573. DOI: $10.1183 / 09031936.00166106$

Copp, D. H. \& Cheney, B, (1962). Calcitonin-a hormone from the parathyroid which lowers the calcium-level of the blood. Nature, 193(4813), 381-382.

DOI:10.1038/193381a0.
Costa, M. C., Silva, G., Ramos, L. V., Staempfli, H. R., Arroyo, L. G., Kim, P. \& Weese, J. S. (2015). Characterization and comparison of the bacterial microbiota in different gastrointestinal tract compartments in horses. Veterinary Journal, 205(1), 74-80. DOI: $10.1016 /$ j.tvjl.2015.03.018

Dahaba, A. A., Rehak, P. H. \& List, W. F. (2003). Procalcitonin and C-reactive protein plasma concentrations in nonseptic uremic patients undergoing hemodialysis. Intensive Care Medicine, 29(4), 579-583.

DOI: $10.1007 /$ s00134-003-1664-8

Dandona, P., Nix, D., Wilson, M. F., Aljada, A., Love, J., Assicot, M. \& Bohuon, C. (1994). Procalcitonin increase after endotoxin injection in normal subjects. The Journal of Clinical Endocrinology and Metabolism, 79(6), 1605-1608. DOI: $10.1210 /$ jcem.79.6.7989463

Davies, J, (2015). Procalcitonin. Journal of Clinical Pathology, 68(9), 675-679. DOI: $10.1136 /$ jclinpath-2014-202807

Delèvaux, I., André, M., Colombier, M., Albuisson, E., Meylheuc, F., Bègue, R. J., Piette, J.C. \& Aumaître, 0. (2003). Can procalcitonin measurement help in differentiating between bacterial infection and other kinds of inflammatory processes? Annals of the Rheumatic Diseases, 62(4), 337-340.

DOI: $10.1136 /$ ard.62.4.337

Dicks, L. M. T., Botha, M., Dicks, E. \& Botes, M., (2014). The equine gastro-intestinal tract: An overview of the microbiota, disease and treatment. Livestock Science, 160, 69-81.

DOI: http://dx.doi.org/10.1016/j.livsci.2013.11.025

Domenech, V. S., Nylén, E. S., White, J. C., Snider, R. H., Becker, K. L., Landmann, R. \& Müller, B. (2001). Calcitonin gene-related peptide expression in sepsis: postulation of microbial infection-specific response elements within the calcitonin I gene promoter. Journal of Investigative Medicine, 49(6), 514-521. DOI: $10.2310 / 6650.2001 .33628$.

Dornbusch, H. J., Strenger, V., Sovinz, P., Lackner, H., Schwinger, W., Kerbl, R. \& Urban, C. (2008). Noninfectious causes of elevated procalcitonin and C-reactive protein serum levels in pediatric patients with hematologic and oncologic disorders. Supportive Care in Cancer, 16(9), 1035-1040. DOI: 10.1007/s00520-007-0381-1.

Dou, Y. H., Du, J. K, Liu, H. L. \& Shong, X. D. (2013). The role of procalcitonin in the identification of invasive fungal infection-a systemic review and meta-analysis. Diagnostic Microbiology and Infectious Disease. 76(4), 464 -469 .

DOI: 10.1016/j.diagmicrobio.2013.04.023. 
Durnaś, B, Wątek, M, Wollny, T, Niemirowicz, K, Marzec, M, Bucki, R, \& Góźdź, S. (2016). Utility of blood procalcitonin concentration in the management of cancer patients with infections. Journal of OncoTargets and Therapy, 88(9), 469-475.

DOI: $10.2147 / O T T . S 95600$

Ercan, N, Tuzcu, N, Başbuğ, O. \& Oğrak Y, Z. (2014). The Evaluation of Important Biomarkers in Healthy Cattle. Journal of the Faculty of Veterinary Medicine, Kafkas University, 20(5), 749-755. DOI: $10.9775 / \mathrm{kvfd} .2014 .11066$

Ercan, N, Tuzcu, N, Başbug, O, Tuzcu, M. \& Alim, A. (2016). Diagnostic value of serum procalcitonin, neopterin, and gamma interferon in neonatal calves with septicemic colibacillosis. The Journal of Veterinary Diagnostic Investigation, 28(2), 180-183. DOI: $10.1177 / 1040638715626488$.

Ertuğrul, Ö. \& Ertuğrul, M. B. (2005). Procalcitonin and Infection. Klimik Journal, 74 (2), 59-62.

Floras, A. N. K. (2014). Biomarker and cytokine measurements in dogs with endotoxemia. PhD thesis, The University of Guelph, Ontario, Canada.

Floras, A. N. K, Holowaychuk, M. K, Hodgins, D. C, Marr, H. S, Birkenheuer, A, Sharif, S, Bersenas, A. M. \& Bienzle, D. (2014). Investigation of a commercial ELISA for the detection of canine procalcitonin. Journal of Veterinary Internal Medicine, 28(2):599-602.

DOI: $10.1111 /$ jvim.12309.

Gilbert, D. N. (2011). Procalcitonin as a biomarker in respiratory tract infection. Clinical Infectious Diseases, 18 (S4), S346-S350. DOI: $10.1093 / \mathrm{cid} / \operatorname{cir} 050$

Giunti, M., Peli, A., Battilani, M., Zacchini, S., Militerno, G. \& Otto, C. M. (2010). Evaluation of CALC-I gene (CALCA) expression in tissues of dogs with signs of the systemic inflammatory response syndrome. Journal of Veterinary Emergency and Critical Care (San Antonio), 20(5), 523527.

DOI:10.1111/j.1476-4431.2010.00575.x

Grace, E. \& Turner, R. M. (2014). Use of procalcitonin in patients with various degrees of chronic kidney disease including renal replacement therapy. Clinical Practice, 15 (15), 1761-1767. DOI: $10.1093 / \mathrm{cid} /$ ciu732

Hatzistilianou, M. (2010). Diagnostic and prognostic role of procalcitonin in infections. Scienti6ic World Journal, 7 (10), 1941-1946.

DOI: $10.1100 /$ tsw.2010.181.

Hillyard, C. J., Myers, C., Abeyasekera, G., Stevvensvenson, J. C., Craig, R. K. \& MacIntyre, I. (1983). Katacalcin; A new plasma calcium-lowering hormone. Lancet, 7 (8329), 846848.
Hirakata, Y., Yanagihara, K., Kurihara, S., Izumikawa, K., Seki, M., Miyazaki, Y. \& Kohno, S. (2008). Comparison of usefulness of plasma procalcitonin and C-reactive protein measurements for estimation of severity in adults with community acquired pneumonia. Diagnostic Microbiology and Infectious Disease, 61(2): 170-174. DOI:10.1016/j.diagmicrobio.2008.01.014

Hoffmann, G., Totzke, G., Seibel, M., Smolny, M., Wiedermann, F. J. \& Schobersberger, W. (2001). In vitro modulation of inducible nitric oxide synthase gene expression and nitric oxide synthesis by procalcitonin. Critical Care Medicine, 29(5),556-116. DOI: 10.1097/01.CCM.0000025215.25664.AD

Jacobs, J. W., Lund, P. K., Potts, J. T., Bell, N. H. \& Habener, J. F. (1981). Procalcitonin is a glycoprotein. Journal of Biological Chemistry, 256(6), 2803-2807.

Kuzi, S., Aroch, I., Peleg, K., Karnieli, O., Klement, E. \& Dank, G. (2008). Canine procalcitonin messenger RNA expression. Journal of Veterinary Diagnostic Investigation, 20(5), 629. 633.

DOI: $10.1177 / 104063870802000516$

LeMoullec, J. M., Jullienne, A., Chenais, J., Lasmoles, F., Guliana, J. M., Milhaud, G. \& Moukhtar, M. S. (1984). The complete sequence of human preprocalcitonin. FEBS Letters, 167 (1), 93-97.

DOI: 10.1016/0014-5793(84)80839-X

Lee, H. (2013). Procalcitonin as a biomarker of infectious diseases. The Korean Journal of Internal Medicine, 84(3), 285-291.

DOI: $10.3904 / \mathrm{kjim} .2013 .28 .3 .285$

Leli, C., Ferranti, M., Moretti, A., Al Dhahab, Z. S., Cenci, E. \& Mencacci, A. (2015). Procalcitonin levels in gram-positive, gram-negative, and fungal bloodstream infections. Disease Markers, 1-8. DOI: http://dx.doi.org/10.1155/2015/701480

Linscheid, P., Seboek, D., Nylén, E. S., Langer, I., Schlatter, M., Becker, K. L., Keller, U. \& Müller, B. (2003). In vitro and in vivo calcitonin I gene expression in parenchymal cells: A novel product of human adipose tissue. Endocrinology, 144(12), 5578-5584.

DOI: $10.1210 /$ en.2003-0854

Linscheid, P., Seboek, D., Schaer, D. J., Zulewski, H., Keller, U. \& Muller, B. (2004). Expression and secretion of procalcitonin and calcitonin gene-related peptide by adherent monocytes and by macrophage-activated adipocytes. Critical Care Medicine, 98(8) 1715-1721. DOI: 10.1210/en.2003-0854

Liu, H. H., Guo, J. B., Geng, Y. \& Su, L. (2015). Procalcitonin: present and future. Irish Journal of Medical Science, 740 (3), 597-605.

DOI: $10.1007 / \mathrm{s} 11845-015-1327-0$ 
Martinez, J. M., Wagner, K. E., Snider, R. H., Nylén, E. S., Muller, B., Sarani, B., Becker, K. L. \& White, J. C. (2001). Late immunoneutralization of procalcitonin arrests the progression of lethal porcine sepsis. Surgical infections, 2(3), 192-201. DOI: 10.1089/109629601317202678

Maruna, P, Nedelníková, K, \& Gürlich, R. (2000). Physiology and genetics of procalcitonin. Physiological Research, 49, (Suppl 1), S57-S61.

Mehanic, S. \& Baljic, R. (2013). The importance of serum procalcitonin in diagnosis and treatment of serious bacterial infections and sepsis, Materia Sociomedia, 25 (4), 277-281.

DOI: $10.5455 / \mathrm{msm} .2013 .25 .277-281$

Meisner, M. (1997). Procalcitonin. A new, innovative marker for severe infection and sepsis biochemical and clinical aspects. 2nd rev ed. Berlin, Germany: BrahmsDiagnostica.

Meisner, M. (2014). Update on procalcitonin measurements. Annals of Labaratory Medicine, 34(4), 263-273. DOI: 10.3343/alm.2014.34.4.263

Meisner, M., Scholer, A., Tschaikowsky, K. \& Schüttler, J. (1996). Procalcitonin inhibits camp, prostaglandin E and thromboxane B-production of human lymphocytes. Acta Anaesthesiologica Scandinavica, 40, 251-252.

Meisner, M., Lohs, T., Huettemann, E., Schmidt, J., Hueller, M. \& Reinhart, K. (2001). The plasma elimination rate and urinary secretion of procalcitonin in patients with normal and impaired renal function. European Journal of Anaesthesiology, 18(2), 79-87.

Melendi, G. A., Laham, F. R., Monsalvo, C., Casellas, J. M., Israele, V., Polack, N. R., Kleeberger, S. R. \& Polack, F. P. (2007). Cytokine profiles in the respiratory tract during primary infection with human metapneumovirus, respiratory syncytial virus or influenza virus in infants, Pediatrics, 120(6), e854-415.

DOI: $10.1542 /$ peds.2006-3283

Mol, J. A., Kwant, M. M, Arnold, I. C. \& Hazewinkel, H. A. (1991). Elucidation of the sequence of canine (pro)calcitonin. A molecular biological and protein chemical approach. Regulatory Peptides, 91(3), 189-195.

DOI: http://dx.doi.org/10.1016/0167-0115(91)90082-R

Montagna, M. T., Coretti, C., \& Caggiano, G. (2011) Procalcitonin: a possible marker of invasive fungal infection in high risk patients? Journal of Preventive Medicine and Hygiene, 52(1), 38-39.

Morgenthaler, N. G., Struck, J., Chancerelle, Y., Weglöhner, W., Agay, D., Bohuon, C., Suarez-Domenech, V., Bergmann, A. \& Müller, B. (2003). Production of procalcitonin (PCT) in non-thyroidal tissue after LPS injection. Hormone and Metabolic Research, 35(5), 290295.

DOI: $10.1055 / \mathrm{s}-2003-41304$
Moya, F, Nieto, A. \& R-Candela, J. L. (1975) Calcitonin biosynthesis: evidence for a precursor. European Journal of Biochemistry, 55(2), 407-413. DOI: $10.1111 / \mathrm{j} .1432-1033.1975 . t b 02176 . x$

Müller, B., White, J. C., Nylén, E. S., Snider, R. H., Becker, K. L. \& Habener, J. F. (2001). Ubiquitous expression of the calcitonin_1 gene in multiple tissues in response to sepsi s. Journal of Clinical Endocrinology and Metabolism, 86 (1), 396-404. DOI: $10.1210 /$ jcem.86.1.7089

Nylén, E. S., Whang, K. T., Snider, R. H., Steinwald, P. M., White, J. C. \& Becker, K. L. (1998). Mortality is increased by procalcitonin and decreased by an antiserum reactive to procalcitonin in experimental sepsis. Critical Care Medicine, $26(6$ ), 1001-1006.

Okada, Y., Minakami, H., Tomomasa, T., Kato, M., Inoue, Y., Kozawa, K., Kimura, H. \& Morikawa, A. (2004). Serum procalcitonin concentration in patients with Kawasaki disease. Journal of Infection, 48(2), 199-205. DOI: http://dx.doi.org/10.1016/j.jinf.2003.08.002

Pusterla, N., Magdesian, K. G., Mapes, S., \& Leutenegger, C. M. (2006). Expression of molecular markers in blood of neonatal foals with sepsis. American Journal of Veterinary Research, 67(6), 1045-1049. DOI: 10.2460/ajvr.67.6.1045

Ricciotti, E. \& FitzGerald, G. A. (2011). Prostaglandins and Inflammation. Arteriosclerosis, Thrombosis, and Vascular Biology, 31(5), 986-1000. DOI: 10.1161/ATVBAHA.110.207449

Rieger, M., Kochleus, C., Teschner, D., Rascher, D., Barton, A. K., Geerlof, A., Kremmer, E., Schmid, M., Hartmann, A. \& Gehlen, H. (2014). A new ELISA for the quantification of equine procalcitonin in plasma as potential inflammation biomarker in horses, Analytical and Bioanalytical Chemistry, 406(22), 5507-5512. DOI: $10.1007 / \mathrm{s} 00216-014-7944-\mathrm{z}$

Russwurm, S., Wiederhold, M., Oberhoffer, M., Stonans, I., Zipfel, P. F. \& Reinhart, K. (1999). Molecular aspects and natural source of procalcitonin. Clinical Chemistry and Laboratory Medicine, 37(8), 789-797. DOI: 10.1515/CCLM.1999.119

Schneider, H. G. \& Lam, Q. T. (2007). Procalcitonin for the clinical laboratory: A review. Pathology, 39(4), 383-390. DOI: $10.1080 / 00313020701444564$

Steinbach, G, Bölke, E, Grünert, A, Orth, K. \& Störck, M. (2004). Procalcitonin in patients with acute and chronic renal insufficiency. Wiener Klinische Wochenschrift, 116(24), 849-853. DOI: $10.1007 / \mathrm{s} 00508-004-0279-6$

Tavares, E., Maldonado, R. \& Miñano, F. J. (2007). Nprocalcitonin: central effects on feeding and energy homeostasis in rats. Endocrinology, 148(4), 1891-901. DOI: $10.1210 /$ en.2006-0792 
Teschner, D. Rieger, M., Koopmann, C. \& Gehlen, H. (2015). Procalcitonin in horses with an acute colic. Pferdeheilkunde, 31(4), 371-377.

Toribio, R. E., Kohn, C. W., Leone, G. W., Capen, C. C. \& Rosol, T. J. (2003). Molecular cloning and expression of equine calcitonin, calcitonin gene-related peptide-I, and calcitonin gene-related peptide-II. Molecular and Cellular Endocrinology, 199(1-2), 119-128. DOI:10.1016/s0303-7207(02) 00289-7.

Wagner, K. E., Martinez, J. M., Vath, S. D., Snider, R. H., Nylén, E..S., Becker, K. L., Müller, B. \& White, J. C. (2002). Early immunoneutralization of calcitonin precursors attenuates the adverse physiologic response to sepsis in pigs. Critical Care Medicine, 30(10), 2313-2321.

DOI: $10.1097 / 01 . C C M .0000030446 .45432 .43$

Wei, J. X., Verity, A., Garle, M., Mahajan, R. \& Wilson, V. (2008). Examination of the effect of procalcitonin on human leucocytes and the porcine isolated coronary artery. British Journal of Anaesthesia 100(5), 612-621. DOI: https://doi.org/10.1093/bja/aen073

Wiedermann, F. J., Kaneider, N., Egger, P., Tiefenthaler, W., Wiedermann, C. J., Lindner, K. H. \& Schobersberger, W. (2002). Migration of monocytes in response to procalcitonin, Critical Care Medicine, 30(5), 1112-1117.

Y1lmaz, Z., Ilcol, Y. O. \& Ulus, I. H. (2008). Endotoxin increases plasma leptin and ghrelin levels in dogs. Critical Care Medicine, 36(3):828-33.

DOI: 10.1097/01.CCM.0B013E3181611F5AA.

Zannoni, A., Giunti, M., Bernardini, C., Gentilini, F., Zaniboni, A., Bacci, M. L. \& Forni, M. (2012). Procalcitonin gene expression after LPS stimulation in the porcine animal model. Research in Veterinary Science, 93(2), 921-927. DOI: 10.1016/j.rvsc.2011.09.011. 